\title{
Annual heat balance and equilibrium temperature of Lake Aegeri, Switzerland
}

\author{
David M. Livingstone ${ }^{1}$ and Dieter M. Imboden ${ }^{2}$ \\ Hydrobiologisch-limnologische Station, Seestraße 187, CH-8802 Kilchberg, Switzerland \\ ${ }^{2}$ EAWAG, Environmental Physics, CH-8600 Dübendorf, Switzerland
}

Key words: Heat balance; heat exchange coefficient; equilibrium temperature; Lake Aegeri.

\begin{abstract}
The mean heat budget of Lake Aegeri, Switzerland, is $950 \mathrm{MJ} \cdot \mathrm{m}^{-2}$, comparable to that of neighbouring lakes. The annual variation in the net heat flux can be adequately described using a six-term heat balance equation based on 12 years of monthly mean meteorological and surface temperature data. Although the magnitude of the net heat flux is dominated by the radiative terms of the equation, the one-month backward shift of the net flux and total heat content extrema from the solstices and equinoxes respectively is due to the phase shift of the non-radiative with respect to the radiative terms. A linear approximation was used to express the net heat flux in terms of a heat exchange coefficient and an equilibrium temperature. The former varies from 17 to $28 \mathrm{~W} \cdot \mathrm{m}^{-2} \cdot \mathrm{K}^{-1}$ in the course of a year; fluctuations in the latter are found to depend mainly on fluctuations in cloud cover and relative humidity, whilst the effect of fluctuations in air temperature and wind speed is slight.
\end{abstract}

\section{Introduction}

The net heat balance of a lake can generally be well accounted for in terms of five main heat exchange processes (see for example Edinger et al., 1968; Sweers, 1976; LAWA, 1977; Marti and Imboden, 1986). These are: the absorption of direct and diffuse global (short-wave) radiation from sun and atmosphere respectively; the absorption of infra-red (long-wave) radiation from the atmosphere; the emission of infra-red (long-wave) radiation from the lake surface; the exchange of latent heat between lake surface and atmosphere due to evaporation and condensation; and the convective exchange of sensible heat between lake surface and atmosphere. A sixth process, that of sensible heat gain and loss associated with throughflow, can be important in some lakes and will also be considered here. The influence of other heat exchange processes, such as the reflection of infra-red radiation by mountains surrounding the lake or heat exchange between waterbody and sediments, has been 


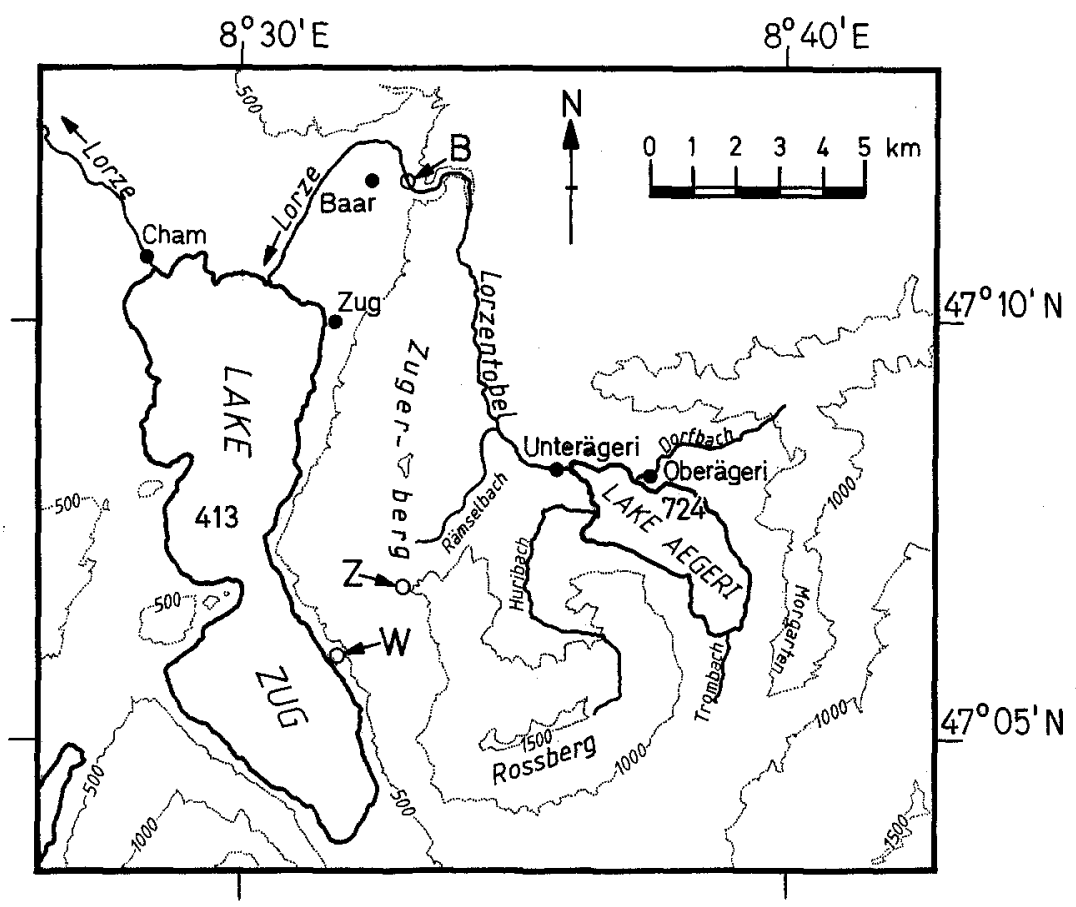

Figure 1. Location of Lake Aegeri, the Zugerberg ( $Z$ ) and Walchwil (W) meteorological stations and the Baar hydrological station (B). Contours and lake elevation in $\mathrm{m}$ a. s. 1 .

assumed to be negligible in similar studies of other Swiss lakes (Kuhn, 1978; Marti and Imboden, 1986) and will not be considered further here.

Comprehensive studies of the heat budgets of Swiss lakes and of the influences of meteorological factors on the heat balance equation are rare. Kuhn $(1977,1978)$ computed the terms of the heat balance equation for Lake Zürich on the basis of monthly mean meteorological and limnological data; Marti and Imboden (1986) investigated heat fluxes through the surface of Lake Sempach using data of high temporal resolution.

Lake Aegeri, the subject of this study, is situated at $724 \mathrm{~m} \mathrm{a.s.1}$. in the northern foothills of the Swiss Alps (Fig. 1) and has a maximum depth of $83 \mathrm{~m}$, a surface area of $7.28 \mathrm{~km}^{2}$ and a volume of $356 \times 10^{6} \mathrm{~m}^{3}$. The calculation of the terms of the heat balance equation for this lake required a comprehensive set of limnological and meteorological data.

\section{Limnological data}

\section{Temperature}

A total of 114 temperature profiles was measured above the deepest point of the lake by the Zug Cantonal Laboratory in the years 1972-83. These profiles were interpo- 


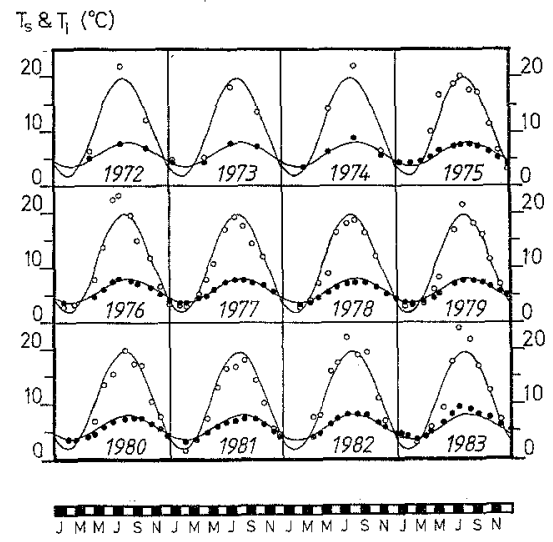

Figure 2. Surface temperature $T_{5}$ (white) and mean lake temperature $T_{1}$ (black) of Lake Aegeri from 1972-83. Curves: sinusoidal approximations.

lated using a cubic spline function (IMSL, 1982) with an interpolation interval of $1 \mathrm{~m}$. Isobath areas obtained from the Swiss Federal Office for the Protection of the Environment (unpubl. data) were also interpolated at the same depths using the same method. This allowed the computation of the heat content of 83 water layers, each of $1 \mathrm{~m}$ thickness (under the assumption of horizontal homogeneity with respect to temperature). The heat content of the lake was obtained by summing the heat contents of the individual layers. As the measured profiles represent instantaneous temperature values which are affected by internal waves and seiching, a large error is inherent in the computed heat content (Marti and Imboden, 1986). This error can only be reduced by averaging over several years. The time series of heat content and of surface temperature were therefore also interpolated with cubic splines in order to obtain daily values of both parameters, which were then averaged to yield monthly means (Fig. 2). These monthly means were further averaged over the 12 years $1972-83$ to yield the 12 monthly means which were to be used as input to the heat balance model.

\section{Hydrology}

The volume transport of the River Lorze, the outflow from Lake Aegeri, is measured on a regular basis at the Baar hydrological station (Fig. 1; Swiss Federal Office for the Protection of the Environment, National Hydrological Service, 1981). The catchment area of Lake Aegeri $\left(48.0 \mathrm{~km}^{2}\right)$ makes up $57 \%$ of the total catchment area of the hydrological station $\left(84.7 \mathrm{~km}^{2}\right)$ : the outflow of the lake was therefore estimated to be $57 \%$ of the corresponding volume transport measured at Baar. The mean lake outflow was computed to be $1.77 \mathrm{~m}^{3} \cdot \mathrm{s}^{-1}$.

Maurer (1913) carried out an investigation of evaporation from Lake Aegeri between December 1911 and November 1912. The annual evaporation of $740 \mathrm{~mm}$ calculated by him corresponds to a mean water loss by the lake of $0.17 \mathrm{~m}^{3} \cdot \mathrm{s}^{-1}$. The 

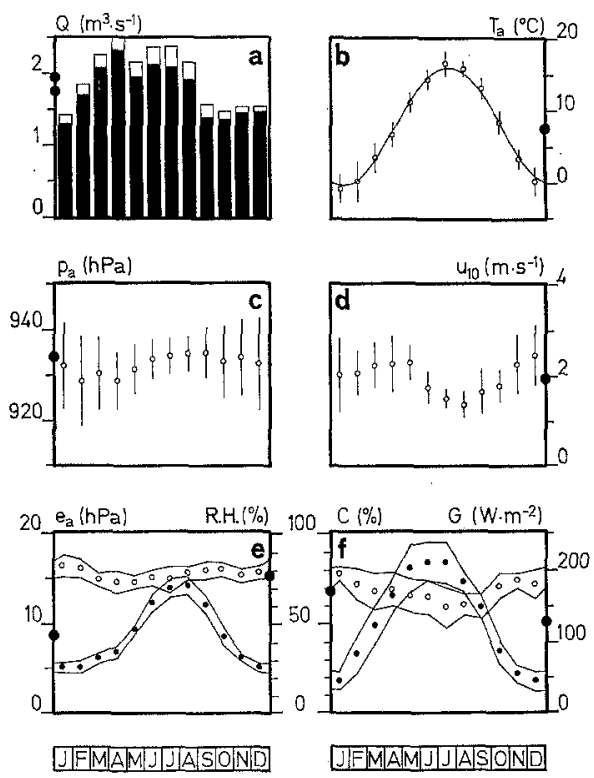

Figure 3. Monthly mean meteorological and hydrological parameters of Lake Aegeri. (MM = monthly mean, black dots on the side of figures; SD1 = standard deviation of measured values; $\mathrm{SD} 2=$ standard deviation of monthly means; $\mathrm{n}$ = number of values). a) Outflow $\mathrm{Q}$ (black, MM, 1951-81: Swiss Federal Office for the Protection of the Environment, National Hydrological Service, 1981); Evaporation (white, values from 1912-13: Maurer, 1913). b) Air temperature $T_{a}$ (MM, SD2 calculated from daily means, 1950-83). Curve: sinusoidal approximation. c) Air pressure $\mathrm{p}_{\mathrm{a}}$ (MM, SD1, 1972-79, $\mathrm{n}=678-744$ per month). d) Wind speed $10 \mathrm{~m}$ above lake surface $u_{10}$ (MM, SD2, 1972-83). e) Water vapour pressure $e_{a}$ (black) and relative humidity R. H. (white) (MM, 1972-83). SD2 calculated from SD2 of $\mathrm{T}_{\mathrm{a}}$ according to Sweers (1976). f) Global radiation G (black) and cloud cover C (white) (MM, 1972-83). SD2 calculated from $\mathrm{SD} 2$ of $\mathrm{G}_{\mathrm{ZH}}, \mathrm{C}$ and $\mathrm{C}_{\mathrm{ZH}}$ according to equation [4].

evaporative water loss cited for Lake Aegeri by Moser (1975) and by Baumgartner et al. (1983) $\left(680 \mathrm{~mm}\right.$, i. e. $\left.0.16 \mathrm{~m}^{3} \cdot \mathrm{s}^{-1}\right)$ does not differ significantly from Maurer's (1913) results. The annual variation in outflow and evaporation for Lake Aegeri is illustrated in Fig. 3 a.

\section{Meteorological data}

Most of the meteorological data used in this study were obtained from two stations maintained by the Swiss Meteorological Office situated between Lake Aegeri and Lake Zug (Fig. 1). The Zugerberg station (975 m a.s.1.) lies $6 \mathrm{~km}$ west of Lake Aegeri and $251 \mathrm{~m}$ above the lake surface. The Walchwil station ( $449 \mathrm{~m}$ a. s. 1.), which is no longer extant, lay $8 \mathrm{~km}$ south-west of Lake Aegeri and $275 \mathrm{~m}$ below the level of the lake surface. Measurements at these two stations were carried out thrice a day, at $7.30,13.30$ and 19.30. Data on global radiation were obtained from the synoptic weather station in Zürich (556 m a. s. 1.), $23 \mathrm{~km}$ north of the lake. 


\section{Air temperature}

The daily mean air temperature at the surface of Lake Aegeri was calculated under the assumption of a linear decrease in air temperature with increasing height above sea level. During the period 1972-80, air temperature data were available from both Zugerberg and Walchwil, and the daily mean air temperature at Lake Aegeri was estimated by linear interpolation between the two stations. The Walchwil station was shut down at the end of 1980 , which meant that calculations for the period 1981-83 had to be carried out based on the Zugerberg measurements alone. These were corrected to the surface of Lake Aegeri using the monthly mean temperature gradients calculated for the two stations during their period of simultaneous operation (1972-80). Monthly means and standard deviations and a sinusoidal regression curve calculated for the composite period 1972-83 are shown in Fig. 3 b.

\section{Air pressure}

The air pressure at the lake surface was calculated from the Zugerberg air pressure and the computed mean air temperature between Zugerberg and Lake Aegeri using the barometer formula (Liljequist and Cehak, 1979). A statistical analysis of the 8766 values obtained for the period $1972-79$ yielded an overall mean of $932.0 \mathrm{hPa}$ and a standard deviation of $7.4 \mathrm{hPa}$. Monthly means and standard deviations do not differ greatly from these values (Fig. $3 \mathrm{c}$ ).

\section{Wind speed}

The Zugerberg meteorological station is situated considerably higher than the lake surface in a relatively exposed location. It was therefore necessary to determine the form of the relationship between the wind speeds measured at the Zugerberg station (Windmaster Mark II anemometer; wind speed averaged over 5-10 minutes and read off by eye thrice a day: SMA, 1981) and the corresponding wind speeds prevailing at the surface of the lake over a representative period. Accordingly, between 30.1. 82 and 20.4.82, wind speed measurements were carried out at a height of $10 \mathrm{~m}$ above ground level using two Woelfle anemometers (Wilh. Lambrecht KG, Göttingen, FRG), the first being located $20 \mathrm{~m}$ north of the already existing Zugerberg Windmaster anemometer and the second in the Oberägeri bathing area about $5 \mathrm{~m}$ from the lake shore (Fig. 1). As the bathing area is situated on a piece of flat land projecting into the lake, it was assumed that wind speeds there were representative of those prevailing over the lake as a whole. The Weibull distribution (Weibull, 1951 ) is often made use of when it is desired to express the cumulative wind speed probability distribution in terms of an analytical function (e.g. Justus et al., 1976). No significant difference (at the $5 \%$ significance level) could be detected between the Weibull coefficients of the Zugerberg Windmaster data during the period 30.1. 82-20.4. 82 and during the months of October to March, 1971-79. It can therefore be assumed that the wind speeds measured during the period of investigation were representative of those prevailing during a normal winter. 
Because of the differing measuring methods and averaging intervals employed, the Woelfle and Windmaster anemometers did not yield the same values for the measured wind speed. The 5-10 minute mean wind speeds read off from the Windmaster anemometer $\left(\mathrm{u}_{1}\right)$ and the hourly mean wind speeds measured by the Woelfle anemometer $\left(\mathrm{u}_{2}\right)$ were however found to be related linearly $\left(\mathrm{n}=240, \mathrm{~F}_{1,238}=405\right.$, $\left.\alpha=0.001, \mathrm{r}^{2}=63 \%\right)$ :

$$
\mathrm{u}_{2}=0.84 \mathrm{~m} \cdot \mathrm{s}^{-1}+0.54 \cdot \mathrm{u}_{1}
$$

The hourly means $\left(\mathrm{u}_{2}\right)$ were further averaged to obtain daily mean wind speeds $\left(\mathrm{u}_{3}\right)$. It was found that the relationship between these daily means and the corresponding daily mean wind speeds measured at the lake shore $\left(\mathrm{u}_{4}\right)$ was also described well by a linear regression $\left(n=77, F_{1,75}=301, \alpha=0.001, r^{2}=80 \%\right)$. The regression line did not differ significantly (at the $5 \%$ significance level) from the following simple relationship:

$$
\mathrm{u}_{4}=0.90 \cdot \mathrm{u}_{3} .
$$

The daily mean wind speeds at Lake Aegeri during 1972-83 were calculated from the Zugerberg wind data using equations [1] and [2]. Monthly mean wind speeds (= $\mathrm{u}_{10}$ ) are illustrated in Fig. $3 \mathrm{~d}$.

\section{Humidity}

According to Kuhn (1977), the decrease in water vapour pressure with increasing height above sea level is proportional to $\mathrm{e}^{-\mathrm{k} \cdot \mathrm{h}}$, where $\mathrm{h}$ represents a height difference and $\mathrm{k}$ a coefficient which takes on a value between $0.00032 \mathrm{~m}^{-1}$ (July) and $0.00037 \mathrm{~m}^{-1}$ (January). Lake Aegeri lies $251 \mathrm{~m}$ below the Zugerberg meteorological station; the water vapour pressure at the height of the surface of the lake can thus be estimated to be about $9 \%$ higher than the measured value. Fig. $3 \mathrm{e}$ illustrates the annual variation in water vapour pressure and in relative humidity (calculated according to Sweers, 1976) at Lake Aegeri.

\section{Cloud cover}

The degree of cloud cover at Swiss meteorological stations is visually estimated thrice a day and expressed in eighths of the sky. The mean of the six daily observations from the Zugerberg and Walchwil stations (converted into \%) served as a measure of the degree of cloud cover over the lake. Between March and September, the observations made at Zugerberg and Walchwil were very similar: the difference between the monthly mean cloud cover (1972-80) at these two stations did not exceed $6 \%$ of the mean in any one month. Between October and February, on the other hand, as a result of the more frequent occurrence of mist at the lower-lying Walchwil station, this difference increased to between $13 \%$ and $16 \%$ of the mean. Missing observations from Walchwil (1981-83) were replaced with values calculated by 
means of linear regressions from the Zugerberg observations. The degree of cloud cover at Lake Aegeri during the year (Fig. $3 \mathrm{f}$ ) is similar to that found by Urfer (1979) to be typical of the north-facing slope of the Swiss Alps.

\section{Global radiation}

No measurements of global radiation were made either at Zugerberg or Walchwil. It was therefore necessary to calculate the global radiation falling on Lake Aegeri from global radiation measurements made in Zürich coupled with the degree of cloud cover at Zürich and at Lake Aegeri.

The ratio of the global radiation $G$ reaching the earth's surface when the degree of cloud cover is $C$ ( $=0$ to 1 ) to the global radiation $G_{0}$ reaching the earth's surface under cloudless conditions is independent of solar declination and can be expressed empirically as follows (Kasten and Czeplak, 1980):

$$
\mathrm{G} / \mathrm{G}_{0}=1-\mathrm{a} \cdot \mathrm{C}^{\mathrm{b}} .
$$

Coefficient a is found to vary from 0.70 to 0.75 and exponent $b$ from 2.6 to 3.4 in various locations in the Federal Republic of Germany; the values $a=0.72$ and $b=$ 3.2 are representative of the whole of the FRG (Kasten et al., 1984) and will here be assumed to be valid for Switzerland also.

The assumption that $\mathrm{G}_{0}$ has the same value at Lake Aegeri and in Zürich is justified, since the effect of atmospheric turbidity is generally small compared to that of cloud cover (Kasten et al., 1984) and the influence of $251 \mathrm{~m}$ height difference on $\mathrm{G}_{0}$ is negligible (A. Zelenka, pers. comm.). The dependence of the ratio of the global radiation at Lake Aegeri $(\mathrm{G})$ to that at Zürich $\left(\mathrm{G}_{\mathrm{ZH}}\right)$ on the degree of cloud cover at these two locations ( $\mathrm{C}$ and $\mathrm{C}_{\mathrm{ZH}}$ respectively) can therefore be described by the following empirical equation:

$$
\mathrm{G} / \mathrm{G}_{\mathrm{ZH}}=\left(1-0.72 \cdot \mathrm{C}^{3.2}\right) /\left(1-0.72 \cdot \mathrm{C}_{\mathrm{ZH}}{ }^{3.2}\right) \text {. }
$$

The annual variation in $\mathrm{G}$ is illustrated in Fig. $3 \mathrm{f}$.

\section{Heat budget}

The heat content of Lake Aegeri relative to a temperature of $0^{\circ} \mathrm{C}$ is proportional to the mean lake temperature $T_{1}$ shown in Fig. 2. On average (1972-83), it reached a minimum value of $730 \mathrm{MJ} \cdot \mathrm{m}^{-2}$ (st. dev. $= \pm 60 \mathrm{MJ} \cdot \mathrm{m}^{-2}$ ) on February 21 st (st. dev. $=$ $\pm 13 \mathrm{~d}$ ) and a maximum of $1680 \mathrm{MJ} \cdot \mathrm{m}^{-2}$ (st. dev. $= \pm 120 \mathrm{MJ} \cdot \mathrm{m}^{-1}$ ) on August $18 \mathrm{th}$ (st. dev. $= \pm 18 \mathrm{~d}$ ). The total heat budget of the lake is thus $950 \mathrm{MJ} \cdot \mathrm{m}^{-2}$ (st. dev. $=$ $\pm 130 \mathrm{MJ} \cdot \mathrm{m}^{-2}$ ) in an average year. This is comparable to the heat budget calculated by Kutschke (1966) for Lake Zürich $\left(950 \mathrm{MJ} \cdot \mathrm{m}^{-2}\right.$ ) and to that calculated by Marti and Imboden (1986) for Lake Sempach $\left(1100 \mathrm{MJ} \cdot \mathrm{m}^{-2}\right)$ and Lake Baldegg $\left(900 \mathrm{MJ} \cdot \mathrm{m}^{-2}\right)$. 


\section{Influence of ice cover on heat budget}

During part of the winter, Lake Aegeri is frequently partially or completely icecovered (see for example Heuscher, 1906). Ice cover influences the heat budget of a lake both directly (latent heat of fusion) and indirectly (influence on heat exchange processes at the lake surface). Only the direct effect will be considered here. The latent heat of fusion of water is $0.334 \mathrm{MJ} \cdot \mathrm{kg}^{-1}$ and the density of natural ice lies between $835 \mathrm{~kg} \cdot \mathrm{m}^{-3}\left(9 \%\right.$ air content) and $918 \mathrm{~kg} \cdot \mathrm{m}^{-3}$ (air-free) (Neumann and Pierson, 1966). The gain or loss of sensible heat energy by an ice sheet during freezing or melting cannot therefore exceed $307 \mathrm{MJ} \cdot \mathrm{m}^{-3}$ ice $\left(=0.334 \mathrm{MJ} \cdot \mathrm{kg}^{-1} \cdot 918 \mathrm{~kg} \cdot \mathrm{m}^{-3}\right)$. The opening of the ice surface to the public, which does not occur until the ice has reached a thickness of $12 \mathrm{~cm}$ (Zug Cantonal Police, pers. comm.), is normally reported in the local press. A search of the local newspapers from 1972 to 1983 revealed only one occurrence of such a report, in 1981. During freezing or melting of an ice sheet $12 \mathrm{~cm}$ thick, a maximum of $37 \mathrm{MJ} \cdot \mathrm{m}^{-2}$ is converted from latent to sensible heat or vice versa. Only part of the sensible heat will be lost to or gained from the water. The direct effect of freezing and melting on the heat budget of the lake in a normal year is therefore considerably less than $37 \mathrm{MJ} \cdot \mathrm{m}^{-2}$.

\section{Net heat flux}

The net heat flux into a lake can be expressed as follows:

$$
\mathrm{H}=\mathrm{H}_{\mathrm{S}}+\mathrm{H}_{\mathrm{L}}+\mathrm{H}_{\mathrm{B}}+\mathrm{H}_{\mathrm{E}}+\mathrm{H}_{\mathrm{C}}+\mathrm{H}_{\mathrm{F}},
$$

where the six terms on the right-hand side of equation [5] represent the heat fluxes associated with the processes of short-wave absorption $\left(\mathrm{H}_{\mathrm{S}}\right)$, long-wave absorption $\left(\mathrm{H}_{\mathrm{L}}\right)$, long-wave emission $\left(\mathrm{H}_{\mathrm{B}}\right)$, evaporation/condensation $\left(\mathrm{H}_{\mathrm{E}}\right)$, convection $\left(\mathrm{H}_{\mathrm{C}}\right)$ and throughflow $\left(\mathrm{H}_{\mathrm{F}}\right)$. The radiative absorption terms $\left(\mathrm{H}_{\mathrm{S}}\right.$ and $\left.\mathrm{H}_{\mathrm{L}}\right)$ are always positive and the radiative emission term $\left(\mathrm{H}_{\mathrm{B}}\right)$ always negative, whereas the terms representing non-radiative heat exchange $\left(\mathrm{H}_{\mathrm{E}}, \mathrm{H}_{\mathrm{C}}, \mathrm{H}_{\mathrm{F}}\right)$ can take on either positive or negative values.

The net heat flux $\mathrm{H}$ through a lake surface is the time derivative of the heat content of the lake. Monthly mean values of $\mathrm{H}$ calculated from the interpolated values of the heat content are illustrated in Fig. $4 \mathrm{~b}$. They vary from $-86 \mathrm{~W} \cdot \mathrm{m}^{-2}$ in November to $+102 \mathrm{~W} \cdot \mathrm{m}^{-2}$ in May. A change in the lake heat content of $950 \mathrm{MJ} \cdot \mathrm{m}^{-2}$ (the total heat budget) in six months corresponds to a mean net heat flux of $60 \mathrm{~W} \cdot \mathrm{m}^{-2}$ (st. dev. $=$ $\left.\pm 8 \mathrm{~W} \cdot \mathrm{m}^{-2}\right)$.

\section{Short-wave absorption}

The short-wave radiation absorbed by the lake is obtained by multiplying the global radiation $\mathrm{G}$ by an absorption coefficient $\mathrm{A}_{\mathrm{s}}$ :

$$
\mathrm{H}_{\mathrm{S}}=\mathrm{A}_{\mathrm{s}} \cdot \mathrm{G} \text {. }
$$


$A_{s}$ depends on solar declination, atmospheric turbidity and other factors (Kuhn, 1978; Krambeck, 1982). The values of $A_{s}$ given by Kuhn (1978), which lie in the range 0.772 (December) to 0.914 (June), were inserted into equation [6]. $\mathrm{H}_{\mathrm{S}}$ was found to vary from $35 \mathrm{~W} \cdot \mathrm{m}^{-2}$ (December) to $195 \mathrm{~W} \cdot \mathrm{m}^{-2}$ (June); its annual mean was $117 \mathrm{~W} \cdot \mathrm{m}^{-2}$ (Fig. $\left.4 \mathrm{a}\right)$.

\section{Long-wave absorption}

The long-wave absorption term is the most difficult of the six terms to compute and is also the most prone to computational error. The atmosphere is treated as an infrared radiator with an emission coefficient $E_{L}$. The water is assumed to absorb $97 \%$ of the radiation impinging on the lake surface (Anderson, 1954):

$$
\begin{aligned}
& \mathrm{H}_{\mathrm{L}}=0.97 \cdot \mathrm{E}_{\mathrm{L}} \cdot \sigma \cdot \hat{\mathrm{T}}_{\mathrm{a}}^{4} \cdot \\
& \sigma=\text { Stefan-Boltzmann constant }=56.7 \cdot 10^{-9} \mathrm{~W} \cdot \mathrm{m}^{-2} \cdot \mathrm{K}^{-4} \\
& \hat{\mathrm{T}}_{\mathrm{a}}=\text { absolute air temperature }[\mathrm{K}] .
\end{aligned}
$$

Water vapour in the atmosphere is the main source of infra-red radiation; $\mathrm{E}_{\mathrm{L}}$ therefore depends mainly on cloud cover and humidity. There exist several empirical formulae for the determination of $\mathrm{E}_{\mathrm{L}}$ under cloudless conditions (e.g. Brunt, 1932; Anderson, 1954; Swinbank, 1963; Dingman et al., 1968; Idso and Jackson, 1969; LAWA, 1977; Satterlund, 1979). In this study, however, in common with Marti and Imboden (1986), it was decided to use the more meaningful formula of Brutsaert (1975, 1982), which was not determined empirically, but is based on the physical properties of the atmosphere. The results yielded by this formula are, according to Mermier and Seguin (1976) and Aase and Idso (1978), fully comparable to those obtained by the purely empirical formulae. Cloud cover causes an increase in $\mathrm{E}_{\mathrm{L}}$ by a factor of $\left(1+a \cdot C^{2}\right)$, where the coefficient $a$ is dependent on cloud type (Bolz, 1949). This coefficient lies in the range 0.04 (Cirrus) to 0.25 (Nimbostratus). The mean value of the coefficient a for 8 cloud types listed by Brutsaert (1982) is 0.17, a value frequently used in the literature when the cloud type is unknown (e.g. Marti and Imboden, 1986). The emission coefficients thus obtained were multiplied by the factor 1.09 , which was determined according to the optimisation procedure described by Kuhn (1978). By means of this procedure, the emission coefficient $\mathrm{E}_{\mathrm{L}}$ and the wind function $\mathrm{f}$ (treated in a subsequent section), the determination of which is subject to the greatest error, are optimised, so that the difference between $\mathrm{H}$ and the sum of the terms of equation [5] is minimised (optimisation according to IMSL, 1982). The final expression obtained for $E_{L}$ is as follows:

$$
\begin{aligned}
& \mathrm{E}_{\mathrm{L}}=1.09 \cdot\left(1+0.17 \cdot \mathrm{C}^{2}\right) \cdot 1.24 \cdot\left(\mathrm{e}_{\mathrm{a}} / \hat{\mathrm{T}}\right)^{1 / 7} \\
& \mathrm{C}=\text { degree of cloud cover; } \\
& \mathrm{e}_{\mathrm{a}}=\text { water vapour pressure }[\mathrm{hPa}] \\
& \hat{\mathrm{T}}_{\mathrm{a}}=\text { absolute air temperature }[\mathrm{K}]
\end{aligned}
$$


Based on equations [7] and [8], $\mathrm{H}_{\mathrm{L}}$ was found to vary between $257 \mathrm{~W} \cdot \mathrm{m}^{-2}$ (February) and $360 \mathrm{~W} \cdot \mathrm{m}^{-2}$ (July, August) and had an annual mean of $304 \mathrm{~W} \cdot \mathrm{m}^{-2}$ (Fig. $4 \mathrm{a}$ ).

\section{Long-wave emission}

Long-wave radiation is emitted from the surface of a lake according to the StefanBoltzmann law for a "grey body" with an emission coefficient of 0.97 (see for example Edinger et al., 1968; Sweers, 1976; LAWA, 1977; Kuhn, 1977, 1978):

$$
\begin{aligned}
& \mathrm{H}_{\mathrm{B}}=-0.97 \cdot \sigma \cdot \hat{\mathrm{T}}_{\mathrm{s}}^{4} . \\
& \sigma=\text { Stefan-Boltzmann constant }=56.7 \cdot 10^{-9} \mathrm{~W} \cdot \mathrm{m}^{-2} \cdot \mathrm{K}^{-4} \\
& \hat{\mathrm{T}}_{\mathrm{s}}=\text { absolute temperature of lake surface }[\mathrm{K}] .
\end{aligned}
$$

$\mathrm{H}_{\mathrm{B}}$ is not only the most accurately determinable term of equation [5], but also the term with the greatest magnitude. $\mathrm{H}_{\mathrm{B}}$ varies between $-405 \mathrm{~W} \cdot \mathrm{m}^{-2}$ (July, August) and $-320 \mathrm{~W} \cdot \mathrm{m}^{-2}$ (February), and has an annual mean of $-357 \mathrm{~W} \cdot \mathrm{m}^{-2}$ (Fig. $4 \mathrm{a}$ ).

\section{Evaporation/condensation}

The heat loss of a lake occurring as the result of evaporation at the lake surface is described by the following empirical formula:

$$
H_{E}=-f \cdot\left(e_{s}-e_{a}\right) .
$$

The lake loses heat by evaporation when the water vapour pressure $e_{a}$ of the air over the lake falls under the saturation water vapour pressure $e_{s}$ at the temperature of the lake surface. If $\mathrm{e}_{\mathrm{a}}$ exceeds $\mathrm{e}_{\mathrm{s}}$ on the other hand, the lake gains heat by condensation. The function $f$ depends in the main on wind speed. There exist many forms of this function: LAWA (1977) has listed twenty. Sweers (1976) investigated the wind function thoroughly and came to the conclusion that the form of the function suggested by McMillan (1971) yielded the best results for work in temperate zones. Kuhn (1978) added the instability term suggested by Dingman et al. (1968) to McMillan's function to obtain the following:

$$
\begin{aligned}
& \mathrm{f}^{*}=4.4+1.82 \cdot \mathrm{u}_{10}+0.26 \cdot\left(\mathrm{T}_{\mathrm{s}}-\mathrm{T}_{\mathrm{a}}\right) . \\
& \mathrm{u}_{10}=\text { wind speed } 10 \mathrm{~m} \text { above the lake surface }\left[\mathrm{m} \cdot \mathrm{s}^{-1}\right] \\
& \mathrm{f}^{*}=\text { wind function }\left[\mathrm{W} \cdot \mathrm{m}^{-1} \cdot \mathrm{hPa} \mathrm{Pa}^{-1}\right]
\end{aligned}
$$

Kuhn's (1978) optimisation procedure yielded a multiplying factor of 1.09 for the final wind function $f$ (that the value of the multiplying factor for $f$ is the same as that for $E_{L}$ is merely coincidence). Hence:

$$
\mathrm{f}=4.8+1.98 \cdot \mathrm{u}_{10}+0.28 \cdot\left(\mathrm{T}_{\mathrm{s}}-\mathrm{T}_{\mathrm{a}}\right) .
$$


$\mathrm{H}_{\mathrm{E}}$ lies between $-79 \mathrm{~W} \cdot \mathrm{m}^{-2}(\mathrm{July})$ and $-18 \mathrm{~W} \cdot \mathrm{m}^{-2}$ (March) and has an annual mean of $-46 \mathrm{~W} \cdot \mathrm{m}^{-2}$.

The heat lost due to evaporation $\mathrm{H}_{\mathrm{E}}$ is connected to the evaporation $\mathrm{Q}_{\mathrm{E}}$ as follows:

$$
\begin{aligned}
& \mathrm{H}_{E}=-\mathrm{Q} \cdot \mathrm{L} \cdot \mathrm{Q}_{\mathrm{E}} . \\
& \varrho=\text { density of water }=1000 \mathrm{~kg} \cdot \mathrm{m}^{-3} ; \\
& \mathrm{L}=\text { latent heat of evaporation }=2.465 \cdot 10^{6} \mathrm{~J} \cdot \mathrm{kg}^{-1} \text { at } 15^{\circ} \mathrm{C} ; \\
& \mathrm{Q}_{\mathrm{E}}=\text { evaporation }\left[\mathrm{m} \cdot \mathrm{s}^{-1}\right] .
\end{aligned}
$$

The annual mean of $Q_{E}$ calculated from equations [10], [13], and the measured meteorological data is $19 \cdot 10^{-9} \mathrm{~m} \cdot \mathrm{s}^{-1}$, i. e. $590 \mathrm{~mm} \cdot \mathrm{a}^{-1}$. This underestimates the annual mean evaporation given by Maurer (1913) by $20 \%$, and that given by Moser (1975) and Baumgartner et al. (1983) by $13 \%$.

\section{Convection}

The ratio of $H_{C}$ to $H_{E}$ is proportional to the ratio of $\left(T_{s}-T_{a}\right)$ to $\left(e_{s}-e_{a}\right)$ (Dingman et al., 1968). The constant of proportionality is called the Bowen coefficient $R$ (Bowen, 1926). Hence, from equation [10]:

$$
H_{C}=-R \cdot f \cdot\left(T_{s}-T_{a}\right) .
$$

$\mathrm{R}$ is proportional to air pressure and has the value $0.65 \mathrm{hPa} \cdot \mathrm{K}^{-1}$ at standard atmospheric pressure (1013 hPa) (Sweers, 1976). At the mean air pressure of $932 \mathrm{hPa}$ prevailing at Lake Aegeri, $\mathrm{R}$ therefore takes on the value $0.60 \mathrm{hPa} \cdot \mathrm{K}^{-1} \cdot \mathrm{H}_{\mathrm{C}}$ varies from $-30 \mathrm{~W} \cdot \mathrm{m}^{-2}$ (October, November) to $+1 \mathrm{~W} \cdot \mathrm{m}^{-2}$ (March) and has an annual mean of $-15 \mathrm{~W} \cdot \mathrm{m}^{-2}$ (Fig. $\left.4 \mathrm{a}\right)$.

\section{Throughflow}

It is assumed here that the influence of groundwater and wastewater on the heat balance is negligible. Under the further assumption that the temperature of the outflow (the River Lorze) is identical to that of the lake surface $\left(T_{s}\right), H_{F}$ is computed as follows:

$$
\begin{aligned}
& \mathrm{H}_{\mathrm{F}}=\mathrm{Q} \cdot \mathrm{c}_{\mathrm{p}} \cdot \varrho \cdot\left(\mathrm{T}_{\mathrm{z}}-\mathrm{T}_{\mathrm{s}}\right) / \mathrm{A}_{0} . \\
& \mathrm{Q}=\text { lake outflow }\left[\mathrm{m}^{3} \cdot \mathrm{s}^{-1}\right] \\
& \mathrm{A}_{0}=\text { lake surface area }=7.28 \cdot 10^{6} \mathrm{~m}^{2} ; \\
& \mathrm{c}_{\mathrm{p}}=\text { specific heat of water }=4200 \mathrm{~J} \cdot \mathrm{kg}^{-1} \cdot \mathrm{K}^{-1} ; \\
& \varrho=\text { density of water }=1000 \mathrm{~kg} \cdot \mathrm{m}^{-3} ; \\
& \mathrm{T}_{\mathrm{z}}=\text { mean inflow temperature }\left[{ }^{\circ} \mathrm{C}\right] .
\end{aligned}
$$




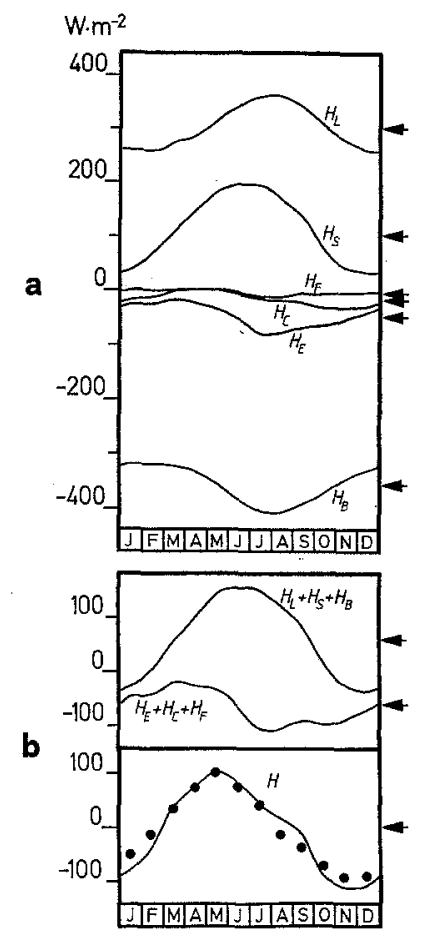

Figure 4. Heat flux terms of Lake Aegeri, computed from the data shown in Figs. 2 and 3 using equations [5] to [15]. Arrows: annual means. $\mathbf{H}$ positive for flux into the water. a) The annual variation in the absorbed short-wave $\left(\mathrm{H}_{S}\right)$ and long-wave $\left(\mathrm{H}_{\mathrm{L}}\right)$ radiation terms, the emitted long-wave radiation term $\left(\mathrm{H}_{\mathrm{B}}\right)$, the evaporation/condensation term $\left(\mathrm{H}_{\mathrm{E}}\right)$, the convective term $\left(\mathrm{H}_{\mathrm{C}}\right)$ and the throughflow term $\left(\mathrm{H}_{\mathrm{F}}\right)$. b) Above: the annual variation in the radiative $\left(\mathrm{H}_{\mathrm{L}}+\mathrm{H}_{\mathrm{S}}+\mathrm{H}_{\mathrm{B}}\right)$ and non-radiative $\left(\mathrm{H}_{\mathrm{E}}+\mathrm{H}_{\mathrm{C}}+\mathrm{H}_{\mathrm{F}}\right)$ components of the heat balance. Below: monthly means of the net heat flux $(\mathrm{H})$, computed from spline-interpolated temperature profiles (points) and as the sum $\mathrm{H}_{\mathrm{L}}+\mathrm{H}_{\mathrm{S}}+\mathrm{H}_{\mathrm{B}}+\mathrm{H}_{\mathrm{E}}+\mathrm{H}_{\mathrm{C}}+\mathrm{H}_{\mathrm{F}}$ (curve).

$\mathrm{H}_{\mathrm{F}}$, which varies between $-10 \mathrm{~W} \cdot \mathrm{m}^{-2}$ (July, August) and $1 \mathrm{~W} \cdot \mathrm{m}^{-2}$ (April) and has an annual mean of $-4 \mathrm{~W} \cdot \mathrm{m}^{-2}$, is small in magnitude compared to the other terms and can be neglected for most practical purposes (Fig. 4 a).

\section{Results of the model}

\section{Total heat balance}

The contributions of the various heat exchange processes to the heat balance are illustrated in Fig. 4 a. Their magnitudes differ greatly. Judged in terms of magnitude alone, the two processes involving the absorption and emission of long-wave radiation by the lake play by far the greatest role in determining the heat balance. The mean value of $\mathrm{H}_{\mathrm{L}}$ is $304 \mathrm{~W} \cdot \mathrm{m}^{-2}$, and that of $\mathrm{H}_{\mathrm{B}}$ is $-357 \mathrm{~W} \cdot \mathrm{m}^{-2}$. These two terms, however, cancel each other out to a large extent: the curves of $\mathrm{H}_{L}$ and $\mathrm{H}_{B}$ illustrated in Fig. 4 a are almost mirror images of one another. The sum $\left(\mathrm{H}_{L}+\mathrm{H}_{B}\right)$ has an 
annual mean of $-54 \mathrm{~W} \cdot \mathrm{m}^{-2}$. It reaches a minimum of $-71 \mathrm{~W} \cdot \mathrm{m}^{-2}$ in December and a maximum of $-39 \mathrm{~W} \cdot \mathrm{m}^{-2}$ in June (the solstice months), and is therefore in phase with the short-wave radiation $\mathrm{H}_{\mathrm{S}}$ absorbed by the lake, which also reaches a minimum $\left(35 \mathrm{~W} \cdot \mathrm{m}^{-2}\right)$ in December and a maximum $\left(195 \mathrm{~W} \cdot \mathrm{m}^{-2}\right)$ in June. This equality of phase results in the mutual reinforcement of the long and short-wave contributions to the total heat balance during the year. The range of $\mathrm{H}_{\mathrm{S}}\left(160 \mathrm{~W} \cdot \mathrm{m}^{-2}\right)$ is about 5 times greater than the range of $\left(\mathrm{H}_{\mathrm{L}}+\mathrm{H}_{\mathrm{B}}\right)\left(32 \mathrm{~W} \cdot \mathrm{m}^{-2}\right)$. Therefore, as shown in Fig. 4 , the curve representing the seasonal variation of the sum of all radiative components $\left(\mathrm{H}_{\mathrm{L}}+\mathrm{H}_{\mathrm{B}}+\mathrm{H}_{\mathrm{S}}\right)$ and that representing the seasonal variation of the global radiation alone $\left(\mathrm{H}_{\mathrm{S}}\right)$ do not differ substantially in form. The resultant influence of the longwave components on the radiation balance of the lake can thus be viewed as merely modifying the effect of the short-wave component, viz. by reducing its annual mean by $54 \mathrm{~W} \cdot \mathrm{m}^{-2}$ and by increasing its range by about $20 \%$.

The remaining, non-radiative components of the heat balance $\left(\mathrm{H}_{\mathrm{E}}, \mathrm{H}_{\mathrm{C}}\right.$ and $\left.\mathrm{H}_{\mathrm{F}}\right)$ are considerably smaller in magnitude than the radiative components (Fig. 4 a), although the evaporative heat flux $\mathrm{H}_{\mathrm{E}}$ (annual mean $=-46 \mathrm{~W} \cdot \mathrm{m}^{-2}$ ) is comparable in magnitude with the sum of the long-wave radiative components $\left(\mathrm{H}_{\mathrm{L}}+\mathrm{H}_{\mathrm{B}}\right)$. The sum of the nonradiative components $\left(\mathrm{H}_{\mathrm{E}}+\mathrm{H}_{\mathrm{C}}+\mathrm{H}_{\mathrm{F}}\right)$ is not in phase with that of the radiative components: the minimum value of the former $\left(-105 \mathrm{~W} \cdot \mathrm{m}^{-2}\right)$ is attained in July/August and its maximum $\left(-19 \mathrm{~W} \cdot \mathrm{m}^{-2}\right)$ in March (Fig. $\left.4 \mathrm{~b}\right)$. Thus, although the net heat flux $\mathrm{H}$ is determined in the main by the radiative components, the effect of the non-radiative components is to force the phase of $\mathrm{H}$ to lead that of $\left(\mathrm{H}_{L}+\mathrm{H}_{B}+\mathrm{H}_{S}\right)$ by about one month. Instead of reaching its extrema in the solstice months, December and June, the net heat flux therefore reaches its extrema in November and May.

The annual variation in the heat content $W$ of the lake is dependent on the variation of the netheat flux $\mathrm{H}$. As Hvaries approximatelysinusoidally and isequal to the derivative $\mathrm{dW} / \mathrm{dt}$, the heat content Wlags the net heat flux $\mathrm{H}$ by $\pi / 2 \mathrm{rad}$, or 3 months. Thus, the extrema of the heat content occur in February and August, and not in March and September, the equinox months, as one would expect by looking at the radiative terms alone. The heat balance of the lake during the course of the year is summarised in Fig. 4 b. The net heat flux $\mathrm{H}$ computed from lake temperature data (points) is generally well described by the model (curve). The magnitudes of the individual terms agree well with those computed by Marti and Imboden (1986) for Lake Sempach using data of high temporal resolution. Between March and July, the model values differ from the values computed from the temperature data by less than $8 \mathrm{~W} \cdot \mathrm{m}^{-2}$. On average, the model overestimates $\mathrm{H}$ by $28 \mathrm{~W} \cdot \mathrm{m}^{-2}$ in August and September and underestimates $\mathrm{H}$ by $22 \mathrm{~W} \cdot \mathrm{m}^{-2}$ between October and February. Kuhn's (1978) model of the heat balance of Lake Zürich also overestimated $\mathrm{H}$ by about $20 \mathrm{~W} \cdot \mathrm{m}^{-2}$ in September and underestimated $\mathrm{H}$ by $15-20 \mathrm{~W} \cdot \mathrm{m}^{-2}$ in November and December, but yielded good agreement in most spring and summer months.

Kuhn (1978) mentioned several possible reasons for the observed deviations between heat flux model and water temperature measurements: the use of monthly means instead of continuous meteorological data; the complexity of heat exchange processes in winter due to inverse temperature profiles and wind influence; ice formation near the lake shore; and the influence of mist and fog on heat exchange. All these reasons are probably also valid in the case of Lake Aegeri. In addition, the 
quality of the meteorological data on which the Lake Aegeri model is based (especially that of the wind speed and global radiation data) is inferior to that of the data employed by Kuhn (1978), which were directly measured at a major meteorological station situated close to the lake under investigation. An important factor influencing the heat balance of Lake Aegeri which has not yet been taken into account is ice cover. The presence of ice, especially if it contains air bubbles or is covered with snow, causes a substantial decrease in the emission and absorption coefficients of the lake surface, reduces the terms $\mathrm{H}_{\mathrm{E}}$ and $\mathrm{H}_{\mathrm{C}}$ to near zero, and also influences the computation of the optimisation factors for $\mathrm{H}_{\mathrm{L}}$ and $\mathrm{H}_{\mathrm{E}}$.

\section{Heat exchange coefficient}

The heat exchange coefficient $\mathrm{A}$ is defined as the negative partial derivative of the net heat flux with respect to the surface temperature of the lake, $T_{s}$ (Kuhn, 1972; Sweers, 1976):

$$
\mathrm{A}=-\delta \mathrm{H} / \delta \mathrm{T}_{\mathrm{s}}
$$

Neglecting the effect of throughflow, A can be computed from the partial derivatives of $\mathrm{H}_{\mathrm{B}}, \mathrm{H}_{\mathrm{E}}$ and $\mathrm{H}_{\mathrm{C}}$ :

$$
\mathrm{A}=-\left(\delta \mathrm{H}_{\mathrm{B}} / \delta \mathrm{T}_{\mathrm{s}}+\delta \mathrm{H}_{\mathrm{E}} / \delta \mathrm{T}_{\mathrm{s}}+\delta \mathrm{H}_{\mathrm{C}} / \delta \mathrm{T}_{\mathrm{s}}\right)
$$

These partial derivatives can be evaluated analytically using equations [9], [10], and [14]. Based on the data from Lake Aegeri, A was found to vary from $17 \mathrm{~W} \cdot \mathrm{m}^{-2} \cdot \mathrm{K}^{-1}$ in March to $28 \mathrm{~W} \cdot \mathrm{m}^{-2} \cdot \mathrm{K}^{-1}$ in July, with an annual mean of $22 \mathrm{~W} \cdot \mathrm{m}^{-2} \cdot \mathrm{K}^{-1}$. These values agree well with those predicted by Kuhn (1977) for lakes at the same height above sea level as Lake Aegeri $\left(17 \mathrm{~W} \cdot \mathrm{m}^{-2} \cdot \mathrm{K}^{-1}\right.$ in January, $34 \mathrm{~W} \cdot \mathrm{m}^{-2} \cdot \mathrm{K}^{-1}$ in July and an annual mean of $\left.25 \mathrm{~W} \cdot \mathrm{m}^{-2} \cdot \mathrm{K}^{-1}\right)$.

\section{Equilibrium temperature}

Edinger et al. (1968) introduced an approximative scheme relating heat transfer at the water-air interface to the heat exchange coefficient $A$ and a so-called equilibrium temperature $\mathrm{T}_{\mathrm{eq}}$, the surface temperature at which the net heat flux $\mathrm{H}$ would be zero. Provided that the surface temperature does not differ strongly from the equilibrium temperature, the heat flux can be described by the linear relationship

$$
H=A \cdot\left(T_{e q}-T_{s}\right)
$$

For constant $A$ and $T_{\text {eq }}$, i. e. constant meteorological conditions, and for a constant mixing depth $z_{\text {mix }}$, the temperature in the mixed layer (which is also the surface temperature $T_{s}$ ) tends to approach the equilibrium temperature $T_{\text {eq }}$ exponentially:

$$
T_{s}(t)=\left[T_{s}(o)-T_{e q}\right] \cdot e^{-k t}+T_{e q}
$$



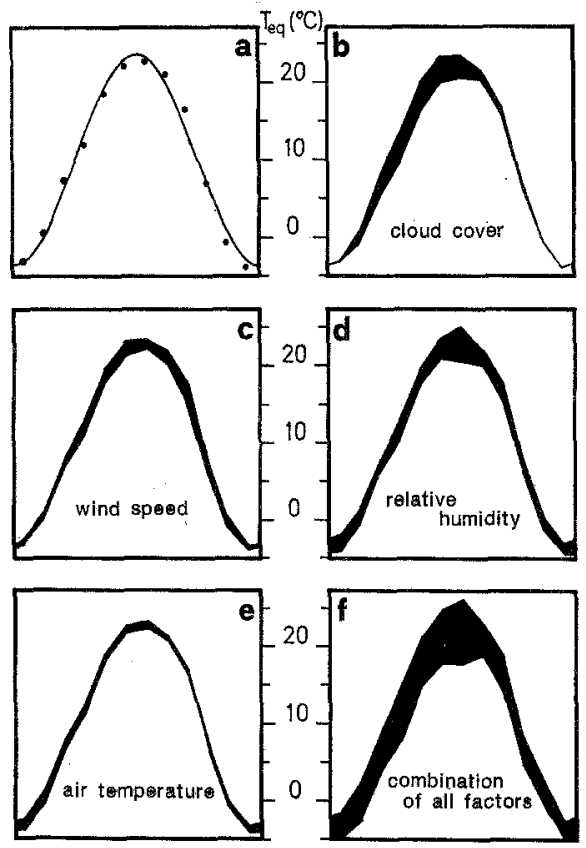

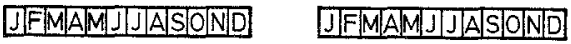

Figure 5. The influence of meteorological factors on the equilibrium temperature $T_{\text {eq }}$ of Lake Aegeri. Varying the monthly mean of a meteorological parameter (Fig. 2) by \pm 2 standard deviations causes a corresponding variation of $\mathrm{T}_{\text {eq }}$ within the range shown. a) Monthly mean equilibrium temperature and sinusoidal regression (equation [20]); variation due to: b) cloud cover; $c$ ) wind speed; d) relative humidity; e) air temperature. f) Monthly mean cloud cover and wind speed increased by 2 standard deviations; monthly mean relative humidity and air temperature decreased by 2 standard deviations (and vice versa).

where $\mathrm{k}=\mathrm{A} /\left(\mathrm{c}_{\mathrm{p}} \cdot \delta \cdot \mathrm{z}_{\mathrm{mix}}\right)$ is the exchange rate (dimension $\left.\mathrm{T}^{-1}\right)$. Due to the strong diurnal variation of $H_{s}$ and other heat flux terms, $T_{e q}$ - and to a lesser extent $A$ - varies over the course of 24 hours. However, the concept of equations [18] and [19] can still be employed for mean conditions over periods of several days or weeks. Note that if heat were to be exchanged across the water-air interface solely by conduction and convection, the equilibrium temperature would be identical to the air temperature (Dingman, 1972). That this is not so is due to the influence of the radiation balance $\left(\mathrm{H}_{\mathrm{S}}+\mathrm{H}_{\mathrm{L}}+\mathrm{H}_{\mathrm{B}}\right)$ and of evaporation/condensation $\left(\mathrm{H}_{\mathrm{E}}\right)$ on the net heat flux.

The mean seasonal variation of the equilibrium temperature of Lake Aegeri, computed from equations [5] to [15] by setting $\mathrm{H}=0$ and solving for $\mathrm{T}_{\mathrm{eq}}=\mathrm{T}_{\mathrm{s}}$, is illustrated in Fig. 5 a. To a first approximation, $T_{\text {eq }}$ varies sinusoidally (Edinger et al., 1968; Kuhn, 1977). In the case of Lake Aegeri, the following sinusoidal regression was found to explain $98.8 \%$ of the variance of $\mathrm{T}_{\mathrm{eq}}$ :

$$
\mathrm{T}_{\text {eq }}\left[{ }^{\circ} \mathrm{C}\right]=10.1+13.6 \sin \omega \cdot(\mathrm{t}-94 \mathrm{~d}) \text {, }
$$

where $\omega=2 \pi / 365.25 \mathrm{rad}$ and $\mathrm{t}=$ Julian day. The $95 \%$ confidence intervals were $\pm 0.8 \mathrm{~K}$ for the constant term, $\pm 1.1 \mathrm{~K}$ for the amplitude and $\pm 15 \mathrm{~d}$ for the phase. 
The temporal variation of the surface temperature $T_{\mathrm{s}}$ was treated by Edinger et al. (1968) and by Kuhn (1977) as a forced oscillation with a sinusoidally varying equilibrium temperature as forcing function. Those factors which can be shown to have a substantial influence on the equilibrium temperature can therefore be assumed also to be important for the surface temperature and for the temperature structure of the lake in general. Neglecting the influence of throughflow, the equilibrium temperature can be seen to depend on five meteorological factors: cloud cover, wind, humidity, air temperature, and global radiation. The global radiation under a cloudless sky $\left(\mathrm{G}_{0}\right)$ at any point on the earth's surface is a constant annual function which remains unaffected by changes in the meteorological variables from year to year. The influence of meteorological factors on the measured global radiation $(\mathrm{G})$ is restricted to the modification of $\mathrm{G}_{0}$ by cloud cover, as expressed in equation [3]. Changes in the shape of the equilibrium temperature curve occurring from year to year are thus the result of variations in just four of the above-mentioned meteorological factors: cloud cover, wind, humidity, and air temperature.

In order to estimate the relative importance of these four factors for the equilibrium temperature, they were, independently of one another, each increased and decreased by two standard deviations and $\mathrm{T}_{\mathrm{eq}}$ recalculated. The results are presented in Figs. 5 b-e. On the basis of the curves shown in these figures it can be stated that fluctuations in the equilibrium temperature are brought about primarily by fluctuations in the degree of cloud cover and in the relative humidity. This agrees with the results obtained by Marti and Imboden (1986), who found that short-term fluctuations in the net heat flux $\mathrm{H}$ depend mainly on the global radiation and evaporation/ condensation terms $\left(\mathrm{H}_{\mathrm{S}}\right.$ and $\left.\mathrm{H}_{\mathrm{E}}\right)$. These terms depend in turn primarily on cloud cover and humidity, respectively. The influence of cloud cover, however, appears to be limited to spring and summer; in autumn and winter it is negligibly small (Fig. 5 b). Additionally, a decrease in the degree of cloud cover below the mean in any season is found to have almost no effect on the equilibrium temperature. The difference between reducing the degree of cloud cover (annual mean $=68 \%$ ) by 2 standard deviations (i.e. by an average $16 \%$, yielding $52 \%$ cloud cover in the mean) and setting the degree of cloud cover directly to zero is insignificant for the resulting equilibrium temperature: the effect of the difference on $T_{\text {eq }}$ would not be noticeable in Fig. 5 b. On the other hand, however, $T_{\text {eq }}$ reacts very sensitively to an increase in the degree of cloud cover above the mean, but only in spring and summer. Fluctuations in the relative humidity give rise to considerable fluctuations in $\mathrm{T}_{\mathrm{eq}}$ in summer, but only to relatively small fluctuations in the other seasons. The influence of wind speed and air temperature on $\mathrm{T}_{\mathrm{eq}}$ is found to be comparatively slight during the whole year.

Strictly, the effects on the equilibrium temperature of fluctuations in cloud cover, wind speed, relative humidity and air temperature should not be considered independently of one another, since these factors tend to be strongly linked. It is however apparent that cloud cover and humidity play a greater role in the determination of the equilibrium temperature of lakes than do wind and air temperature. The subordinate role played by the latter factor is especially surprising in view of the many attempts which have been made to determine the surface temperature of lakes empirically on the basis of air temperature alone (e. g. McCombie, 1959; Kutschke, 
1966; Dingman, 1972; Webb, 1974). The fact that air temperature fluctuations do not seem to have a significant influence on the equilibrium temperature is due to two processes which, to a large extent, cancel one another out. An increase in the air temperature tends, on the one hand, to bring about an increase in $T_{e q}$ by causing an decrease in the convective heat flux, whilst on the other hand, assuming the relative humidity to remain constant, it tends to bring about a decrease in $\mathrm{T}_{\text {eq }}$ by causing a reduction in the water vapour pressure and thus increasing evaporative heat loss to the atmosphere at the lake surface.

As pointed out by Marti and Imboden (1986), the influence of the wind on the heat balance of a lake is not confined to its influence on the evaporation/condensation and convection terms. Wind-induced vertical mixing tends to reduce heat loss at the lake surface by reducing the surface temperature by an amount which depends not only on wind speed, but also on other factors such as the temperature structure of the body of the lake. In modelling the net heat flux $\mathrm{H}$, the influence of wind-mixing is implicitly taken into account as the surface temperature $\mathrm{T}_{\mathrm{s}}$ acts as an input variable to the model. In modelling fluctuations in the equilibrium temperature, however, this is not so, as the surface temperature is in this case the unknown variable (when $\mathrm{H}=$ $0, T_{s}=T_{e q}$ ). It is thus probable that the influence of the wind on the equilibrium temperature is greater than illustrated in Fig. $5 \mathrm{c}$. A thorough investigation of the effect of wind speed on the equilibrium temperature would necessitate the employment of a vertical mixing model; this, however, lies beyond the scope of the present study.

Fig. $5 \mathrm{f}$ illustrates the effect on $\mathrm{T}_{\mathrm{eq}}$ of two extreme constellations of meteorological factors which are unlikely to occur under natural conditions. One results in a high, the other in a low equilibrium temperature. The actual monthly mean equilibrium temperature therefore probably always lies within the limits shown in this figure.

\section{ACKNOWLEDGMENTS}

Water temperature data from Lake Aegeri were made available to us by Zug Cantonal Laboratory, and meteorological data by the Swiss Meteorological Office. We would like to thank Dr. G. Genssler, Dr. A. Zelenka and Mr. W. Eckert of the latter institution for their valuable help and advice in dealing with the meteorological data and Dr. F. Schanz of the University of Zürich Limnological Station for some helpful general comments and suggestions. We are indebted to Major A. Klossner, Commandant of the Frühbühl Military Penal Colony on Zugerberg mountain, and Mr. C. Blattmann, owner of the Oberägeri bathing facility, for permission to install anemometers on their land, and also to Dr. U. Rütter, Ms. U. Steinemann and Mr. R. Mosimann for their help in installing and removing the anemometers and associated gear. This project was supported in part by Swiss National Science Foundation grant 3.125-0.81.

\section{REFERENCES}

Aase, J. K. and S. B. Idso, 1978. A comparison of two formula types for calculating long wave radiation from the atmosphere. Water Resour. Res. 14: 623-625.

Anderson, E. R., 1954. Energy budget studies. In: Waterloss investigations: Lake Hefner Studies, U. S. Geol. Surv. Prof. Paper vol. 269, pp. 71-118.

Baumgartner, A., E. Reichel and G. Weber, 1983. Der Wasserhaushalt der Alpen (Kartenteil). Munich: R. Oldenbourg Verlag, 343 pp. 
Bolz, H. M., 1949. Die Abhängigkeit der infraroten Gegenstrahlung von der Bewölkung. Z. Meteorol. 3; 201-203.

Bowen, I. S., 1926. The ratio of heat losses by conduction and by evaporation from any water surface. Phys. Rev. 27: 779-787.

Brunt, D., 1932. Notes on radiation in the atmosphere: I. Quart. J. Roy. Meteorol. Soc. 58: 389-420.

Brutsaert, W. H., 1975. On a derivable formula for long-wave radiation from clear skies. Water Resour. Res. 11: 742-744.

Brutsaert, W. H., 1982. Evaporation into the atmosphere. Dordrecht: D. Reidel, 299 pp.

Dingman, S. L., 1972. Equilibrium temperatures of water surfaces as related to air temperature and solar radiation. Water Resour. Res. 8: 42-49.

Dingman, S. L., W.F. Weeks and Y.C. Yen, 1968. The effects of thermal pollution on river ice conditions. Water Resour. Res. 4: 349-362.

Edinger, J.E., D.W. Duttweiler and J.C. Geyer, 1968. The response of water temperatures to meteorological conditions. Water Resour. Res. 4: 1137-1143.

Heuscher, J., 1906. Beiträge zu einer Monographie des Aegerisees. Schweiz. Fisch. Z. 14 (Suppl.): $1-59$.

Idso, S. B. and R. D. Jackson, 1969. Thermal radiation from the atmosphere. J. Geophys. Res. 74: 5397-5403.

IMSL, 1982. IMSL library reference manual, 9th edition, Houson: IMSL.

Justus, C. G., W. R. Hargraves and A. Yalcin, 1976. Nationwide assessment of potential output from wind-powered generators. J. Appl. Meteor. 15: 673-678.

Kasten, F. and G. Czeplak, 1980. Solar and terrestrial radiation dependent on the amount and type of cloud. Solar energy 24: 177-189.

Kasten, F., K. Dehne, H. D. Behr and U. Berghalter, 1984. Die räumliche und zeitliche Verteilung der diffusiven und direkten Sonnenstrahlung in der Bundesrepublik Deutschland. West German Fed. Ministr. for Res. and Technol., Res. Rept. BMFT-FB-T 84-125. German Weather Service, Meteorol. Observ. Hamburg, June 1984, 128 pp.

Krambeck, H. J., 1982. Solar energy and quanta in Baltic lakes. Arch. Hydrobiol. 95: 197-206.

Kuhn, W., 1972. Physikalisch-meteorologische Überlegungen zur Nutzung von Gewässern zu Kühlzwekken. Arch. Met. Geoph. Biokl., Ser. A, 21: 95-122.

Kuhn, W., 1977. Berechnung der Temperatur und Verdunstung alpiner Seen auf klimatologisch-thermodynamischer Grundlage. Rept. No.70, Swiss Meteorol. Office, 46 pp.

Kuhn, W., 1978. Aus Wärmehaushalt und Klimadaten berechnete Verdunstung des Zürichsees. Vjschr. naturf. Ges. Zürich, 123: 261-283.

Kutschke, I., 1966. Die thermischen Verhältnisse im Zürichsee zwischen 1937 und 1963 und ihre Beeinflussung durch meteorologische Faktoren. Vjschr. naturf. Ges, Zürich 111: 47-124.

LAWA (Länderarbeitsgemeinschaft Wasser), 1977. Grundlagen für die Beurteilung der Wärmebelastungen von Gewässern, Part 1, Binnengewässer, 2nd edition, Mainz: LAWA-Arbeitsgruppe Wärmebelastung der Gewässer, $123 \mathrm{pp}$.

Liljequist, G. H. and K. Cehak, 1979. Allgemeine Meteorologie, 2nd edition, Braunschweig: F. Vieweg, $385 \mathrm{pp}$.

Marti, D.E. and D.M. Imboden, 1986. Thermische Energieflüsse an der Wasseroberfläche: Beispiel Sempachersee. Schweiz. Z. Hydrol. 48 (2), 196-229.

Maurer, J., 1913. Über die Größe der jährlichen Verdunstung auf Schweizer-Seen am nordalpinen Fuß. Meteorol. Z. 30: 209-213.

McCombie, A. M., 1959. Some relations between air temperatures and the surface water temperature of lakes. Limnol. Oceanogr. 4: 252-258.

McMillan, W., 1971. Heat dispersal - Lake Trawsfynydd cooling studies. In: Symposium on freshwater biology and electrical power generation, part I, session 1, pp 41-80.

Mermier, M. and B. Seguin, 1976. Comments on "On a derivable formula for long-wave radiation from clear skies" by W. Brutsaert. Water Resour. Res. 12: 1327-1328.

Moser, R., 1975. Hydrologische Studie des Kantons Zug. Rept. 457-3, Tiefbauamt, Canton Zug, 11 pp.

Neumann, G. and W. J. Pierson, 1966. Principles of physical oceanography. Englewood Cliffs: Prentice Hall, $545 \mathrm{p}$.

Satterlund, D. R., 1979. An improved equation for estimating long-wave radiation from the atmosphere. Water Resour. Res. 15: 1649-1650. 
SMA (Schweizerische Meteorologische Anstalt), 1981. Annalen der Schweizerischen Meteorologischen Anstalt, vol. 118.

Sweers, H.E., 1976. A nomogram to estimate the heat-exchange coefficient at the air-water interface as a function of wind speed and temperature; a critical survey of some literature. J. Hydrol. 30: $375-401$.

Swinbank, W. C., 1963. Long-wave radiation from clear skies. Quart. J. Roy. Meteorol. Soc. 89: $339-348$.

Swiss Federal Office for the Protection of the Environment, National Hydrological Service, 1981. Hydrologisches Jahrbuch der Schweiz. Bern, 373 pp.

Urfer, C., 1979. Die Klimaregionen der Schweiz: Alpennordhang. In: Klimatologie der Schweiz, vol. II, Regionale Klimabeschreibungen, Part 2, 247-322. Suppl. Annal. Schweiz. Meteor. Anstalt, Jgh 1978.

Webb, M. S., 1974. Surface temperatures of Lake Erie. Water Resour. Res. 10: 199-210.

Weibull, W., 1951. A statistical distribution function of wide applicability. J. Appl. Mech. 18: 293-297.

Received 10 January 1989; accepted 18 October 1989. 